\section{Kastamonu Eğitim Dergisi Kastamonu Education Journal}

Temmuz 2019 Cilt:27 Sayı:4

kefdergi.kastamonu.edu.tr
Başvuru Tarihi/Received: 06.08.2018

Kabul Tarihi/Accepted: 27.10.2018

DOI: $10.24106 /$ kefdergi.3262

\title{
Finlandiya İsveç ve Norveç’te, Okul Öncesi Dönemde Özel Gereksinimli Çocuklara Sunulan Kaynaştırma Eğitimi Uygulamaları
}

\section{Early Childhood Inclusive Education in Finland, Sweden and Norway}

\author{
Esma EROĞLU1 ${ }^{1}$ Ayperi Dikici SIĞIRTMAÇ²
}

\section{Öz}

Türkiye'de okul öncesi dönemde kaynaştrma eğitimine yönelik önemli adımlar atımıştır. Ancak araştırmalar, uygulamaların genel olarak yetersiz kaldığını göstermektedir. Bu noktada farklı ülkelerdeki uygulamaları görmek önemlidir. İngilizce dışında diller konuşulduğu için bilgi birikiminin sınırlı olduğu ve uluslararası öğrenci değerlendirme raporlarında başarı gösteren Finlandiya, Norveç ve İsveç gibi Kuzey Avrupa ülkelerindeki uygulamaların ülkemizdeki uygulamalara ışık tutacağı düşünülmektedir. Bu doğrultuda bu derlemenin amacı Finlandiya, Norveç ve İsveç'te okul öncesi dönemde özel gereksinimli çocuklara sunulan kaynaştırma eğitiminin özelliklerini aktarabilmektir. Çalışma kapsamında bu ülkelerdeki çalışmalar ve yasal dokümanlar taranmıştı. Alan yazın taraması sonucunda önemli sonuçlara ulaşılmıştır: Üç ülkede de okul öncesi eğitim yerel yönetimlerin yetki alanı içindedir ve özel gereksinimli çocuklar kaynaştırma eğitimine dâhil olma hakkına yasal olarak sahiptir. Finlandiya'da erken tanılama ön plandadır. Özel gereksinimli çocukların kaynaştırma eğitimine dâhil olma oranı yüksektir. İsveç'te öğretmen yetiştirme programlarında tüm alanlarda özel gereksinimli bireylere yönelik eğitime yer verilmektedir. Norveç'te özel gereksinimli çocuklar için hazırlanan planlarda disiplinler arası çalışılmaktadır.

Anahtar Kelimeler: kaynaştırma eğitimi, özel eğitim, İsveç, Finlandiya, Norveç

\section{Abstract}

In Turkey, important steps lately have taken to the early childhood inclusive education. However; studies show that the practices remain generally insufficient. At this point, it is important to see that practices in different countries such as Finland, Norway and Sweden which are successful in international student assessment reports. In this respect, the aim of the study is to examine the characteristics of the early childhood inclusive education in Finland, Norway and Sweden. Findings revealed that early childhood education comes under the local authorities and children with special needs have a legal right to enroll preschool classrooms in all three countries. Early diagnosis remains at the forefront and the proportion of children with special needs included into preschool classrooms remains high in Finland. In Sweden, all areas of teacher education programs have special education lessons. Multidisciplinary are worked in preparing plans of children with special needs in Norway.

Keywords: Inclusive education, special education, Sweden, Finland, Norway

1. Hacettepe Üniversitesi, Eğitim Fakültesi, Okul Öncesi Eğitimi AD, Ankara, Türkiye; https://orcid.org/0000-0001-9415-6871

2. Çukurova Üniversitesi, Eğitim Fakültesi, Okul Öncesi Eğitimi AD,Adana, Türkiye; https://orcid.org/0000-0002-8167-8467

Atıf / Citation: Eroğlu, E., \& Dikici Sığırtmaçlı, A. (2019). Finlandiya İsveç ve Norveç’te, okul öncesi dönemde özel gereksinimli çocuklara sunulan kaynaşttrma eğitimi uygulamaları. Kastamonu Education Journal, 27(4), 1705-1712. doi:10.24106/kefdergi.3262 


\section{Extended Abstract}

Introduction: In Turkey, important steps lately have taken towards the implementations of inclusive education that are offered children with special needs in early childhood. Although there are legal arrangements for the participation of special needs children in preschool education institutions, studies show that the practices remains generally insufficient. Practices in northern European countries such as Finland, Norway and Sweden which are successful in international student assessment reports such as PISA are expected to shed light on the practice in our country, as knowledge about their practices is limited because their spoken languages are spoken outside of English. Accordingly, this paper aims to examine characteristics of inclusive education that is offered children with special needs in early childhood in Finland, Norway and Sweden. For this purpose, academic studies and legal documents made in these countries have examined.

Finland: Early Childhood Education comes under the local authorities in Finland and children with special needs have a legal right to enroll to preschool education classrooms with their peers. Specialist support could be provided if the children need in preschool classrooms. Early identification and inclusion of children with special needs remain at the forefront. For this reason, multidisciplinary teams which included nurses, language therapists and psychologist assesses children needs in transition to primary school.

Sweden: In Sweden, all areas of the teacher education programs provide training for special needs individuals. As Finland, Early Childhood Education comes under the local authorities in Sweden. Although children with special needs have a legal right to enroll to preschool education classrooms with their peers, they sometimes enroll units with special resources. School principals are responsible for preparing individual plans for children.

Norway: As Finland and Sweden, Early Childhood Education comes under the local authorities in Norway and children with special needs have a legal right to enroll to preschool education classrooms with their peers. Additionally, children have a legal right to receive individual plans for their needs. Multidisciplinary teams are worked in preparing and practicing individual plans in Norway. Preschools, which have more special needs children, could receive additional help from the central government and municipalities.

Generally, leaving the local authorities of inclusive education, staff facilities, financial supports in these countries, and high proportion of special needs children in preschool classrooms could be reflected implementations of Turkey. 


\section{Giriş}

Okul öncesi dönemde etkili bir kaynaştırma eğitiminin nasıl uygulanacağı uzun yıllardır üzerinde çalışılan önemli bir araştrma konusudur. Kaynaştırma eğitimi, çocukların gereksinimleri doğrultusunda kaynaştırma eğitimine dâhil olan çocuk sayısı, katılan çocukların akranları ile geçirdiği süreler ve eğitime katılan profesyoneller gibi çeşitli boyutlarda değişim gösterebilmektedir (Hurley ve Horn, 2010). Bu noktada ülkemizdeki uygulamaların iyileştirilebilmesi için farklı ülkelerdeki olumlu uygulamaları görmek önemlidir.

Dünyada kaynaştırma eğitimi, 1994 yılındaki Dünya Özel Eğitim Konferansında (World Conference on Special Needs Education: Access and Quality) kaynaştırma eğitimini teşvik eden politika değişikliklerini içeren Salamanca Bildirgesinin (The Salamanca Statement) 92 ülke tarafindan imzalanması ile büyük bir ivme kazanmıştır. Bildirgeye göre kaynaştırma eğitimin başarısı büyük ölçüde erken tanılama, değerlendirme ve özel gereksinimli çocukların eğitim sürecine aktif katIımına bağıdır. Ayrıca, alt yaşına kadar olan çocuklar için erken çocukluk bakım ve eğitim programları; fiziksel, zihinsel ve sosyal gelişimi ilerletmek için yeniden düzenlenmeli ya da geliştirilmiş olmalıdır. Bu programlar, elverişsiz koşulların kötüleşmesini önlemede birey, aile ve toplum için temel bir değere sahiptir ve kaynaştırma eğitimi ilkesini kabul etmelidir (United Nations Educational Scientific and Cultural organization [UNESCO], 1994).

Türkiye'de ise 80'li yıllarda başlayan düzenlemeler 1997 yılında Özel Eğitim Kanununun yürürlüğe girmesi ile hızlanmıştır (Diken, Rakap, Diken, Tomris ve Çelik, 2016). Özel gereksinimli çocukların normal gelişim gösteren akranları gibi okul öncesi eğitim kurumlarına devam etmeleri ise Özel Eğitim Hizmetleri Yönetmeliği'nin 11.maddesi ile zorunlu hale getirilmiştir (Millî Eğitim Bakanlığı [MEB], 2018). Bu bağlamda son yıllarda okul öncesi dönemde kaynaştrma eğitimi uygulamaları artmış ve her yıl okul öncesi eğitim kurumlarına daha fazla sayıda özel gereksinimli çocuk devam etmeye başlamıştir (Acarlar, 2013).

Türkiye'de yürürlükte olan Okul Öncesi Eğitim Programında okul öncesi eğitim kurumlarındaki özel gereksinimli çocuklar için uyarlamalar yapılmasına ve özel gereksinimli çocukları desteklemede dikkat edilmesi gereken noktalara da yer verilmiştir. Öğretmenlerin bu çocuklar için bireysel eğitim planı (BEP) hazırlamaları ve uygulamaları gerektiğinden de bahsedilmektedir (MEB, 2013). Ayrıca Okul Öncesi Eğitim Kurumları Yönetmeliğinde, özel gereksinimli çocukların okul öncesi eğitim kurumlarına yerleştirilmelerinde dikkate alınacak noktalara yer verilmiştir. Yönetmeliğe göre, 37-66 ay arasındaki çocuklar için rehberlik araştırma merkezlerinde oluşturulan Özel Eğitim Değerlendirme Kurulunca rapor düzenlenmektedir. Bu rapor sonucunda, ağır düzeyde zihinsel yetersizliği ve birden çok yetersizliği olmamak şartiyla özel gereksinimli çocuklar, 10 çocuk bulunan sınıflarda ikiden, 20 çocuk bulunan sınıflarda ise birden fazla olmayacak şekilde okul öncesi eğitim kurumlarına kaydedilmektedirler (MEB, 2006).

Her ne kadar özel gereksinimli çocukların okul öncesi eğitim kurumlarına katılmaları ile ilgili yasal düzenlemeler bulunsa da uygulamalarda farklılıklar olabilmektedir. Türkiye'de okul öncesi dönemde kaynaştırma eğitimi ile ilgili yapılan çalışmalar incelendiğinde, çalışmalarının büyük çoğunluğunun öğretmenlerin kaynaştırma eğitimine ilişkin görüş ve tutumlarını inceleyen çalışmalar (Altun ve Gülben, 2009; Artan ve Uyanık Balat, 2003; Özaydın ve Çolak, 2011; Kale, Sığırtmaç, Nur ve Abbak, 2016; Sucuoğlu, Bakkaloğlu, İ̧̧cen Karasu, Demir ve Akalın, 2013; Sarı, Çeliköz ve Seçer, 2009; Temel, 2000); ebeveynlerin kaynaştırma eğitimine ilişkin tutum ve davranışları ile ilgili çalışmalar (Öncü ve Batu, 2005; Tuş ve Çiftçi Tekinarslan, 2013) ile hem ebeveynlerin hem de öğretmenlerin tutum ve görüşlerini ele alan çalışmalar (Çulhaoğlu İmrak, 2009; Koçyiğit, 2015) olduğu görülmektedir. Bu çalışmalar ile genel olarak ebeveyn ve öğretmenlerin bakış açıları ile uygulamada ortaya çıkan zorlukların ortaya konması amaçlanmıştı. Ayrıca uygulamada karşılaşılan zorlukları çeşitli ölçütler açısından değerlendiren çalışmalar da mevcuttur (Çerezci, 2015; Küçük Doğaroğlu ve Bapoğlu Dümenci, 2015; Sart, Ala, Yazlık ve Kantaş Yılmaz, 2004; Tufan ve Yıldıım, 2013). Tüm bu çalışmalar birlikte ele alındığında Türkiye'de kaynaştırma eğitimi uygulamalarının gelişmekte olduğu ancak genel olarak yetersiz kaldığı görülmektedir. Örneğin Çerezci (2015), okul öncesi eğitim kurumlarını kaynaştırma eğitimi açısından değerlendirdiği çalışmasında özel gereksinimli çocuklar için destek hizmetlerinin, sınıf içi öğrenme ortamının ve öğretmenlerin kaynaştırma eğitimine yönelik bilgi düzeylerinin yetersiz olduğunu tespit etmiştir. Benzer bir şekilde Koçyiğit (2015) kaynaştırma eğitimi uygulamalarını ebeveyn ve öğretmenlerin görüşleri doğrultusunda incelediği çalışmasında; kaynaştırma uygulamalarında yetersiz materyal, kalabalık sınıflar, özel gereksinimli çocukların ulaşım sorunları, eğitim ortamı kaynaklı sorunlar ile yönetici, ebeveyn ve öğretmen kaynaklı sorunlar olabildiğini ortaya koymuştur. Bu noktada ülkemizde kaynaştrma eğitiminin uygulanmasındaki eksiklikleri düzeltmek için farklı ülkelerde yapılan uygulamaları görmek önemlidir.

Özellikle Kuzey Avrupa gibi İngilizce dışında farklı dillerin konuşulduğu ve PISA gibi uluslararası öğrenci değerlendirme programlarında yüksek başarı gösteren bölgelerdeki uygulamaların incelenmesi önemlidir. Bu ülkelerdeki olumlu uygulamaların ortaya konulması Türkiye'deki uygulamalara yansıttlabilecektir. Bu doğrultuda bu derlemenin amacı, Fin- 
landiya, İsveç ve Norveç’te okul öncesi dönemde özel gereksinimli çocuklara sunulan kaynaştirma eğitimi uygulamalarının incelenmesidir. Bu amaç kapsamında bu ülkelerde yapılan akademik çalışmalar ve yasal dokümanlar taranmıştr. Sonuçlar ayrı başlıklar halinde sunulmuştur.

\section{Finlandiya}

Finlandiya'da eğitim, çocukların yaşlarına ve yeteneklerine göre sağlıklı büyümelerini ve gelişmelerini destekleyecek şekilde sağlanmaktadır (The Basic Education Act, 1998). Salamanca Bildirgesi (The Salamanca Statement) Finlandiya da dâhil olmak üzere anlaşmayı imzalayan 92 ülke için kaynaştırma eğitimi ile ilgili yüksek beklentiler sunmaktadır. Bu bildirgenin etkisi 1998 yılındaki Fin Temel Eğitim Yasası (Finnish Basic Education Act) ve 2004 yılındaki Temel Eğitim için Ulusal Program (National Core Curriculum for Basic Education) dokümanlarında görülmektedir. Bu dokümanlar, her çocuğun en yakın yaygın eğitim kurumunda eğitim alma hakkına ve aynı zamanda bireysel destek alma hakkına sahip olması gerektiğini; bireyin yalnızca problemlerine odaklanmak yerine, öğrenme ortamı ve tüm okul toplumunu geliştirme ihtiyacı ile farklı uzmanlık alanlarının üyeleri arasında iş birliğine odaklanmayı vurgulamaktadır (Halinen ve Jarvinen, 2008).

Finlandiya'da çocukların yaygın eğitim kurumlarına dahil olmaları öncelikli olarak sağlanmaktadır (Järvinen, 2007). Okul öncesi dönemde çocukların \%96'sından daha fazlası okul öncesi eğitim alırken, tüm çocukların yaklaşık \%99,7'si temel eğitimi tamamlamaktadır. Çocukların yalnızca \%2'sinden daha azı özel eğitim okullarında eğitim görmektedir (Järvinen, 2007). Özel eğitim, özel gereksinimli çocuklara daha fazla kaynak ve daha özel hedefleri olan bir öğretim olanağı sağladığı için yararlı olduğu düşünülmektedir. Her bakımdan kaynaştırma eğitimi, özel eğitim için bir reform olarak addedilmektedir (Hausstatter ve Jahnukainen, 2014). Ayrıca birçok yönden Fin okul sistemi doğası gereği kaynaşmıştr. Herkes için okul yaklaşımına doğru gelişme, yıllar önce başlamıştır.

Fin eğitim sistemine yön veren yasa eşitliğe ve kaynaştırma ilkesine dayanmaktadır. Eğitimin en önemli amacı, bağımsız bir kişiliğin gelişimini desteklemektir. Aynı zamanda eğitimin ana hedefi herkes için öğrenmeyi en mümkün hale getirmeyi sağlamaktır. Her çocuk önemlidir ve tüm kararlar çocukların bakış açısı düşünülerek alınmaktadır (Järvinen, 2007).

Erken tanılamaya, çocuklar okula başlamadan çok önce odaklanılmaktadır. Çocuk sağlığı klinikleri düzenli olarak bebeklerin ve okul öncesi dönemdeki çocukların sosyal, fiziksel ve zihinsel değerlendirmelerini gerçekleştirmektedir. Hemşire, doktor, dil terapisti ve psikolog içeren disiplinler arası ekipler gelişim riskinin tanımlanması amacıyla değerlendirmeler yapar. Okul öncesi dönemden ilköğretime geçişte çocuk, çocuğun ebeveynleri, okul öncesi sınıfindaki öğretmeni ve ilkokul öğretmeninin içinde bulunduğu bir grup toplant gerçekleştirir. Bu toplantida çocukların sosyal, motor ve konuşma becerilerinde incelenen kayıtlar ve portfolyolarını içeren bilgiler karşılaştrılmaktadır (Sabel, Saxenian, Miettinen, Kristensen ve Hautamäki, 2011).

Anaokullarında kullanılan Temel Eğitim için Ulusal Program’a (National Core Curriculum for Basic Education, 2004) göre, okul öncesi eğitimin temel ilkelerinden birisi çocukların gereksinimleri doğrultusunda eğitim verilmesidir. Programda özel gereksinimli çocuklar için bir bölüm bulunmaktadır. Bu bölümde çocukların gereksinimlerinin belirlenmesi, gereksinimlerine yönelik eğitimin planlanmasında çocuğun sahip olduğu olanakların kullanılması, gerektiğinde uzman desteği, erken tanılama ve bireysel eğitim planları üzerinde durulmaktadır. Bu planlarda çocukların özel gereksinimlerine yönelik değerlendirilmeleri ile etkinlikler için hangi uyarlamaların yapılacağı ve fiziksel çevrede ne gibi değişikliklerin yapılması gerektiğine yer verilir. Bir diğer önemli nokta ise çocuğun eğitim aldığı yer değişse bile desteğin devamlılığının sağlanacak olmasıdır. Ayrıca program kaynaştırma eğitiminin uygulanmasında okul öncesi eğitimi personelleri ve ebeveynler arasındaki iş birliğine dikkat çekmektedir.

Erken çocukluk eğitimi ve erken çocukluk özel eğitimi başka bir yerde de sunulabilir, ancak mevcut düzenleme en yaygın sistem olan anaokulu merkezli günlük bakıma odaklanmaktadır. Gelişimsel veya tibbi problemleri olan çocuklar daima erken çocukluk özel eğitimine katılırlar. Bu eğitim anaokullarında üç şekilde sunulmaktadır:

- Illki bir anaokulundaki ayrı bir grupta sağlanır. Bu gruplarda sekiz özel gereksinimli çocuk, iki özel eğitimci ve iki yardımcı bulunmaktadır. Bu gruplar normal bir anaokulunun parçasıdır ve normal gelişim gösteren çocukların olduğu diğer gruplarla kaynaşmaları genellikle oyun alanında ya da partiler sırasında olur.

- Iikincisi de bütünleşmiş bir anaokulunda sağlanır. Bu grupta 12 çocuk bulunmaktadır. Bu çocuklardan yedi çocuk normal gelişim gösterirken, diğer beş çocuk bazı gelişimsel problemleri olan çocuklardır. Personel ise iki özel eğitim öğretmeni ve iki yardımcıdan oluşur. Bu tür gruplar, benzer gruplara sahip bir anaokulunun parçasıdır.

- Üçüncüsü, normal anaokullarında en sık yer verilendir ve herhangi bir özel eğitimci ya da özel eğitim desteği yer almamaktadır. Grupta desteğe gereksinimi olan çocuklar olması koşuluyla, sınıf mevcudu azaltılabilir. Nadiren,

| Kastamonu Eğitim Dergisi, 27(4), 2019| 
eğer bir özel eğitim öğretmeninin bilgisine ve yeteneğine gereksinim duyulursa kendisinden anaokulunu ziyaret etmesi istenebilir (Takala ve Aunio, 2007). Yardımcı personel olanağı ve okulda özel eğitim öğretmeninin bulunabilmesi Finlandiya erken çocukluk eğitiminde önemli noktalar arasındadır (Ojala, 2010).

Ancak her ülkede olduğu gibi özel gereksinimli çocuklara nerede ve nasıl bir eğitim verileceği çeşitli nedenlerle değişebilmektedir. Örneğin Kivirauma, Klemela ve Rinne'in (2006) Finlandiya'daki ebeveynlerle yaptığı çalışmada, ebeveynlere çocukları için yaygın eğitimdeki kaynaştırma sınıflarını mı yoksa özel eğitim okullarını mı tercih ettikleri sorulmuştur. Araştırma sonucuna göre, daha ciddi boyutta yetersizliği olan çocukların ebeveynlerinin çoğunluğu özel eğitim okullarını tercih ederken; daha hafif düzeyde gereksinimi olan çocukların ebeveynlerinin çoğunluğu en yakındaki anaokulunu tercih etmektedir.

\section{İsveç}

İsveç'te erken çocukluk eğitimi, bakımı ve okul öncesinde kalitenin geliştirilmesi, yerel yönetimlerin yetki alanı içerisinde bulunan önemli konulardır (Swedish National Agency for Education [SNAE], 2011). Finlandiya ile benzer bir şekilde 1994'teki Salamanca Bildirgesi, "Herkes İçin Eğitim (Education for All)" kararı ile kaynaştırma eğitimi fikrini ulusal senaryonun en önüne getirmiştir (Meynert, 2014).

Okul öncesi kurumlarında genellikle bir müdür, üniversite derecesine sahip öğretmenler ve en azından ortaöğretim düzeyinde eğitim almış çocuk bakıcıları bulunmaktadır. Ek olarak, konuşma ve dil terapistleri ya da sağlık servislerinden özel eğitimciler de kurumlara ziyarette bulunabilirler (Lundqvist, Allodi ve Siljehag, 2015). İsveç'te bir anasınıf biriminde 12-25 çocuk bulunabilmektedir. Okullar yılın tüm zamanında ve günün büyük bir bölümünde açıktır (Engdahl, 2004).

İsveç'te içerikle ilgili öğelere ve çevreyle ilişkili role dikkat çekebilmek adına özel eğitim gereksinimi olan çocuklardan sıklıkla özel desteğe gereksinimi olan çocuklar ya da zor durumdaki çocuklar diye bahsedilmektedir (Lundqvist, Allodi ve Siljehag, 2015). Özel gereksinimli çocuklar büyük ölçüde yaygın anasınıfi birimlerine ve bazen de özel kaynakları olan birimlere kathlırlar. İsveç Eğitim Yasası (Swedish Education Act) ve Okul Öncesi Programı (Curriculum for the Preschool) okul öncesi eğitime yön vermektedir (Nilholm, Almqvist, Göransson ve Linqvist, 2013).

İsveç Eğitim Yasasında okul öncesi eğitim politikasında kaynaştırma eğitimi ve anaokulunda kaynaştırma gibi kavramlara açıkça yer verilmemiştir. Ayrıca, okul öncesi birimleri için özel eğitim gereksinimi olan ya da eğitsel zorluk yaşayan çocuklara yönelik alternatif bir eğitsel düzenleme bulunmamaktadır (Education Act, 2010:800; SNAE, 2011). Politika dokümanları amaç odaklıdır ve genel koşullarda anaokullarının ulaşması gerekenlere odaklanmıştı (as cited in Lundqvist, Westling ve Siljehag, 2015; SNAE 2011). Ancak okul öncesi dönemdeki çocukların destek alma hakları üzerinde durulmuştur. Bu destekler okullara bağlı olarak sağlanabileceği gibi başka bir uzman kuruluş tarafindan da sağlanabilmektedir (Swedish Education Act, 2010). Ayrıca, yasa okul müdürünün hızlı bir şekilde çocukların özel gereksinimlerini araştırmasını ve bu çocukların öğrenmelerini desteklemek için gerekli olan önlemleri içeren bir bireysel eğitim planı oluşturmasını zorunlu tutmuştur (Hjörne, 2015). Belediyelerin de sosyal etkinlikler aracılığı ile hangi çocukların böylesi desteğe gereksinimi olduğunu tespit etmesi gerekmektedir (UNESCO, 2012).

Okul Öncesi Programında (Curriculum for the Preschool, 2010) okul öncesi eğitim kurumu müdürünün, çocukların gereksinimi olan özel desteği almalarındaki sorumluluğu açıkça belirtilmiştir. Ayrıca okullarda öğretmenlerin yanı sıra okulda bulunan diğer personelleri de içeren "çalışma ekipleri" bulunmaktadır. Çalışma ekipleri, özel gereksinimli çocuklara gereken teşvik ve desteği sağlamakla yükümlüdür. Okul öncesi eğitim kurumu ise çocukların okul öncesi eğitimi tamamlamalarından ve ilkokula geçişini kolaylaştırmaktan sorumludur. Ayrıca, çocuklara bireysel desteğin verilmesi gerektiğini vurgulamaktadır (SNAE, 2011).

Özel gereksinimli çocuklar ve aileleri için yerel yönetimler haricinde il meclisleri de destek sağlamaktadır (Zakirova Engstrand ve Roll-Pettersson, 2014). il meclislerine bağlı yardım merkezleri (Habilitation Centers), düzenli ve sürekli olarak eğitsel ve sosyal, psikolojik ve thbbi (dil terapisi, iş terapisi ve fizyoterapi dahil olmak üzere) yönden destek kaynağıdır (Olsson ve Roll-Petterson, 2012).

\section{Norveç}

Norveç'te kaynaştırma eğitimine yönelik ilk adım 1975 yılında Özel Eğitim Okulları Yasasının (The Special Schools Act), ilk ve Orta Okullar Yasasına (Primary and Secondary Schools Act) entegre edilmesi ile atılmıştr. Salamanca Bildirgesi'nden yaklaşık bir yıl önce 1993 yılı itibari ile özel eğitim veren kurumların birçoğu kapanmıştır ve özel gereksinimli çocukların pek çoğu kaynaştırma eğitime dâhil edilmiştir (Hausstatter ve Thuen, 2014). Bu bağlamda Salamanca Bildirgesi'nin kabul edilmesi özel gereksinimli çocukların gereksinimlerini karşılamada herhangi yeni bir ulusal stratejiyi oluşturmamıştır. 
İlkokula ve okul öncesi eğitime yön veren hem Eğitim Yasası (Education Act) hem de Anaokulu Yasası'nda (Kindergarten Act) özel gereksinimli çocukların okul öncesi eğitim kurumlarına öncelikli olarak katılmaları gerektiği belirtilmiştir. Çocuğun yetersizliğe sahip olup olmadığına karar vermek için bir uzman değerlendirmesi yapılmaktadır. Yerel yönetimler özel gereksinimli çocukların anaokuluna gidebilmesini sağlamaktan sorumludur (Norwegian Ministry of Education and Research, 2015).

Norveç Eğitim ve Araştırma Bakanlığı (Norwegian Ministry of Education and Research) tarafindan hazırlanan Anaokulu Çerçeve Planında (Framework Plan for the Content and Tasks of Kindergarten 2006), anaokullarının özel gereksinimleri olan çocukları keşfetme sorumlulukları üzerinde durulmaktadır. Bu çocuklar için bireysel eğitim planları hazırlanacağına ve bu planlarda eğitim ortamının, sosyal ve fiziksel yönlerinin uyarlanabileceğine değinilmektedir. Dolayısıyla özel gereksinimli tüm çocuklar bireysel bir destek alma hakkına yasal olarak sahiptir.

Yerel yönetimler, özel gereksinimli çocuklar için, ailelerle iş birliği içerisinde Bireysel Eğitim Planının hazırlanmasından sorumludur. Her yerel yönetim, Eğitim ve Psikolojik Servis (EPS) hizmeti sağlar; bu servis ile gerektiğinde uzman değerlendirmeleri yapılabilir. Özel eğitim gereksinimi ailelerin iş birliğinde planlanarak sağlanmakta ve önemli noktalar ailelerin görüşleri üzerine şekillenmektedir. Özel eğitim çoğunlukla anaokulları/bakımevlerinde verilmektedir, ancak aynı zamanda evde de verilebilir. Çocuk daha anaokuluna başlamadan, haftada birkaç saatten 25 saate kadar özel eğitim alabilir. Buna ilaveten çoğu çocuğun kişisel bir yardımcısı vardır (Ingemarsson, n.d). Bünyesinde özel gereksinimli çocuk sayısı fazla olan ya da daha yoğun servislere gereksinim duyan çocuklar olan anaokulları merkezi hükümetten ve belediyelerden ek yardım almaktadır (Engel, Barnett, Anders ve Taguma, 2015).

Okullar, eğer belediye yeterli değilse, idari bölgeden yardım isteyebilir. Her idari bölgede bir tane olan Çocuk Yardım Merkezlerinden (Children Habilitation Centers), rehberlik ve yardım hizmetleri alabilirler. Ailelerin bu servisi alabilmeleri için doktor tavsiyesi gerekmektedir. Çocuk yardım merkezleri hastanelerin bir parçasıdır, ancak disiplinler arası personele sahiptir. Çoğunlukla konuşma terapistlerine ve özel eğitim öğretmenlerine de sahiptir. Eğer belediye yeterli değilse ve özel eğitim ile ilgili desteğe gereksinim duyuyorsa, hükümet düzeyinde geniş bir hizmet yelpazesi sunan Özel Eğitim Ulusal Destek Sisteminden (The National Support System for Special Education [Statped]) destek alabilir. Statped'in genel amacı, özel gereksinimli çocuklara uygun eğitimsel ve gelişimsel koşullar verilmesini sağlamak ve ayni zamanda belediyelerde ve eyalet yönetimlerinde eğitimin sorumluluğundaki bu kurumlara, rehberlik etmek ve desteklemektir. Statped, 0-5 yaş aralığındaki özel gereksinimli çocuklar da erken çocukluk müdahalesi isimli bir bölüme sahiptir (Ingemarsson, n.d).

Genel olarak Norveç'teki özel gereksinimli çocukların büyük çoğunluğu, yerleşmiş kaynaştırma eğitimi fikri ve devlet yardımları ile önemli düzeyde fiziksel ve sosyal olanaklara sahip evlerine en yakın okul öncesi eğitim kurumlarında kaynaştırma eğitimine dâhil olabilmektedir. Ancak sosyo-ekonomik düzeyin düşük veya göçmen nüfusun çok olduğu kırsal bölgelerde gereksinimlerin karşılanmasında zaman zaman sıkıntılar yaşanabilmektedir (Brainerd, 2012).

\section{Sonuç ve Öneriler}

Derleme kapsamında ortaya çıkan sonuçlar ve bu sonuçlar doğrultusunda sunulabilecek öneriler şu şekildedir:

- Üç ülkede de okul öncesi eğitim yerel yönetimlerin yetki alanı içindedir ve özel gereksinimli çocuklar normal gelişim gösteren yaşıtlarıyla birlikte okul öncesi eğitime devam etme hakkına yasal olarak sahiptir.

- Finlandiya'da erken tanılama ön plandadır. Ayrıca özel gereksinimli çocukların büyük çoğunluğu kaynaştırma eğitimine dâhil olmaktadır. Özel gereksinimli çocukların tanılanmasında ve özel gereksinimli çocuklarla çalışılmasında disiplinler arası çalışı maktadır. Bazı okullarda yardımcı personeller bulunmaktadır.

- İsveç'te özel gereksinimli çocuklar çoğunlukla normal gelişim gösteren akranlarıyla aynı sınıflarda okul öncesi eğitim almaktadır. Ancak yapılacak düzenlemelere yönelik yasal bir dayanak bulunmamaktadır. Özel eğitim uzmanları ve dil terapistleri gibi farklı alanlardan uzmanlar zaman zaman okulları ziyaret edebilmektedir. Öğretmen yetiştirme programlarında tüm alanlarda özel eğitim verilmektedir.

- Norveç'te okul öncesi eğitim kurumları özel gereksinimli çocuklar için fiziksel ve sosyal açıdan çeşitli olanaklara sahiptir. Ayrıca özel gereksinimli çocuklar için hazırlanan bireysel eğitim planları ön plandadır. Bu planların hazırlanmasında ve uygulanmasında disiplinler arası çalışılmaktadır. Her çocuk yasal olarak bireysel destek alma hakkına sahiptir.

- Derleme sonucunda ortaya çıkan bu ülkelerdeki kaynaştırma eğitiminin denetiminin yerel yetkililere bırakılması, erken tanılama ve eğitime erken başlanması kaynaştırma eğitimine katılım oranının yüksek olması, okul öncesi eğitim kurumlarında özel eğitim öğretmenlerinin olabilmesi, ek personel olanakları, disiplinler arası çalışmalar ve maddi yardımlar ülkemizdeki uygulamalara da yansıtılabilir. Gelecek araştırmalarda bu ülkelerde yapılan 
uygulamaların doğrudan gözlenerek incelenmesi daha detaylı bir perspektif sağlayacaktır.

- Öte yandan gelecek araştırmalarda araştırma kapsamı genişletilerek daha farklı ülkelerdeki uygulamalar incelenebilir.

\section{Kaynakça}

Acarlar, F. (2013). Kaynaştrrma modeli ve özel gereksinimli çocukların özellikleri. In B. Sucuoğlu ve H. Bakkaloğlu (Ed), Okul öncesinde kaynaştırma öğretmen eğitimi içinde (s. 21-74). Ankara: Kök Yayınclık.

Altun, T. ve Gülben, A. (2009). Okul öncesinde özel gereksinim duyan çocukların eğitimindeki uygulamalar ve karşıllaşlan sorunların öğretmen görüşleri açısından değerlendirilmesi. Selçuk Üniversitesi Ahmet Keleşoğlu Eğitim Fakültesi Dergisi, 28, 253-272.

Artan, İ. ve Uyanık Balat, G. (2003). Okul öncesi eğitimcilerinin entegrasyona iliş̧in bilgi ve düşüncelerinin incelenmesi. Kastamonu Eğitim Dergisi, 11(1), 65-80.

Asbjornett, M., Engelsrud, G.H., \& Hesleth, S. (2014). Inclusion and participation in everyday school life: experiences of children physical (dis)abilities. International Journal of Inclusive Education, 19(2), 199-212.

Basic Education Act of Finland, (1998). Retrieved April 29, 2016 from http://www.finlex.fi/en/laki/kaannokset/1998/en19980628.pdf

Batu, S. Çolak, A. ve Odluyurt, S. (2012). Okul öncesi kaynaştırma. Ankara: Vize Yayıncılık.

Brainerd, J. (2012). Early childhood special education in Norway and the United States: a meta-synthesis. Master of Degree, University of Alaska Southeast, Alaska.

Çerezci, Ö. (2015). Okul öncesi eğitim kurumlarında yapılan kaynaştırma eğitimi uygulamalarının kaynaştırma kriterleri açııından değerlendirilmesi. Yayımlanmamış Yüksek Lisans Tezi, Gazi Üniversitesi, Ankara.

Çulhaoğlu Imrak, H. (2009). Okul öncesi dönemde kaynaştırma eğitimine ilişkin öğretmen ve ebeveyn tutumları ile kaynaştırma eğitimi uygulanan sınıflarda akran ilişkilerinin incelenmesi. Yayımlanmamış Yüksek Lisans Tezi, Çukurova Üniversitesi, Adana.

Diken, I.H., Rakap, S., Diken, Ö., Tomris, G. ve Çelik, S. (2016). Early childhood inclusion in Turkey. Infants \& Young Children, 29(3), 231-238.

Dikici Sığııtmaç, A. ve Dereterla Gül, E. (2010). Okul öncesinde özel eğitim. Ankara: Kök Yayıncılık.

Education Act. (2010:800). Stockholm: Swedish Code of Statute. Retrieved May 14, 2017 from http://www.friendsinternationalcenter. com/advice/the-swedish-education-act/

Engstrand, Z.R, \& Pettersson, L.R. (2014). Inclusion of preschool children with autism in Sweden: attitudes and perceived efficacy of preschool teachers. Journal of Resarch in Special Educational Needs, 14(3), 170-179.

Engdahl, A. (2004). Implementing a national curriculum in Swedish preschools. International Journal of Early Childhood Education, 10(2), 53-78.

Engel, A., Barnett, W.S, Anders, Y., \& Taguma, M. (2015). Early childhood education and care policy review Norway. Retrieved May 18, 2017 from http://www.oecd.org/norway/Early-Childhood-Education-and-Care-Policy-Review-Norway.pdf

Halinen, I., \& Jarvinen, R. (2008). Towards inclusive education: the case of Finland. Prospects: Quarterly Review of Comparative Education, 38, 77-97.

Hotulainen, R., \& Takala, M. (2012). Parents views on the success of integration of students with special education needs. International Journal of Inclusive Education, 18(2), 140-154.

Haug, P. (2014). The practices of dealing with children with special needs in school: a Norwegian perspective. Emotional ana Behavioural Difficulties,19(3), 296-310

Hausstatter, R.S., \& Thuen, H. (2014). Special education today in Norway. Special Education International Perspectives: Practices Across the Globe Advances in Special Education, 28, 181-207.

Hausstatter, R.S, \& Takala, M. (2008). The core of special teacher education: a comparison of Finland and Norway. European Journal of Special Needs Education, 23(2), 121-134.

Hjörne, E. (2015). The narrative of special education in Sweden: History and trends in policy and practice. Discourse: Studies in the Cultural Politics of Education.

Hurley, J.J., \& Horn, E.M. (2010). Family and professional priorities for Inclusive early childhood settings. Journal of Early Intervention, 32(5), 335-350.

Ingemarsson, M. (n.d). Early childhood intervention in Norway. Retrieved April 25, 2017 from https://www.google.

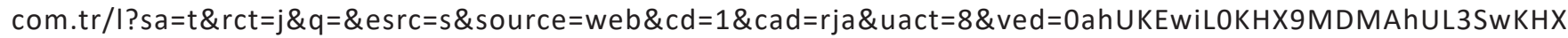
FXD6gQFggbMAA\&url=https\%3A\%2F\%2Fwww.european-agency.org\%2Fsites\%2Fdefault\%2Ffiles\%2Feci_norway. doc\&usg=AFQjCNGetV8xiotRvjV78VugSzRR2ZNHyg\&sig2=V9U9OoUZvZzN4E8SfHDnnw

Järvinen, R. (2007). Finnish National Board of Education. Finland:Regional Preparatory Workshop on Inclusive Education Eastern and South Eastern Europe.

Julia, B. (2012). Early childhood special education in Norway and the United States: A Meta-Synthesis. Master thesis, University of Alaska Southeas, Alaska, United States of America. 
Kale, M., Sığırtmaç, A.D., Nur, İ. ve Abbak, B.S. (2016). Okul öncesi öğretmenlerinin kaynaştırma eğitimi uygulamalarına ilişkin görüşlerinin incelenmesi. Uluslararası Erken Çocukluk Eğitimi Çalışmaları Dergisi, 1(2), 39-48.

Kivirauma, J., Klemel, K., \& Rinne, R. (2006). Segregation, integration, inclusion-the ideology and reality in finland. European Journal of Special Needs Education, 21(2), 117-33.

Koçyiğit, S. (2015). Ana sınıflarında kaynaştırma eğitimi uygulamalarına ilişkin öğretmen-rehber öğretmen ve ebeveyn görüşleri. Uluslararası Türkçe Edebiyat Kültür Eğitim Dergisi, 4(1), 391-415.

Küçük Doğaroğlu, T. ve Bapoğlu Dümenci, S. (2015). Sınıflarında kaynaştırma öğrencisi bulunan okul öncesi öğretmenlerin kaynaştrrma eğitimi ve erken müdahale hakkındaki görüşlerinin incelenmesi. Hacettepe Üniversitesi Sağlık Bilimleri Fakültesi Dergisi, 1, 460-473

Lundqvist, J., Westling, M.A., \& Siljehag, E. (2015). Special educational needs and support provisions in Swedish preschools: a multiplecase study. International Journal of Early Childhood Special Education, 7(2), 273- 293.

Lundqvist, J., Westling, M.A. \& Siljehag, E. (2016). Characteristics of Swedish preschools that provide education and care to children with special educational needs. European Journal of Special Needs Education, 31(1), 124-139.

Millî Eğitim Bakanlığı [MEB]. (2013). Okul öncesi eğitim programı. Resmî Gazete. 09.09.2013/132

Millî Eğitim Bakanlığı [MEB]. (2018). Özel eğitim hizmetleri yönetmeliği. Resmî Gazete. 07.08.2018 /30471.

Meynert, M.J. (2014) Inclusive education and perceptions of learning facilitators of children with special needs in school in Sweden. International Journal of Special Education, 29(2).

National Core Curriculum for Basic Education, (2004). Retrieved April 3, 2017 from http://www.oph.fi/download/47671_core_curricula_ basic_education_1.pdf

Nilholm, C., Almqvist, L., Göransson, K., \& Lindqvist, G. (2013). Is it possible to get away from disability classifications in education? An empirical investigation of the Swedish system. Scandinavian Journal of Disability Research, 15(4), 379- 391.

Norwegian Ministry of Education and Research (2015). The Kindergarten Act, 13.

Ojala, M. (2010). Developing multicultural early childhood education in a finnish context. International Journal of Child Care and Education Policy, 4(1), 13-22.

Olsson, I., \& Roll-Petterson, L. (2012). 'No no, you cannot say that!' Perceptions and experiences of parents of preschool children with intellectual disabilities in Sweden. European Journal of Special Needs Education, 27(1), 69-80.

Öncü, N. ve Batu, E.S. (2005). Normal gelişim gösteren çocuk annelerinin kaynaşttrma uygulamasına ilişkin görüşleri. Ankara Üniversitesi Eğitim Bilimleri Fakültesi Özel Eğitim Dergisi, 6(2) 37-54.

Özaydın, L. ve Çolak, A. (2011). Okul öncesi öğretmenlerinin kaynaşttrma eğitimine ve okul öncesi eğitimde kaynaştırma eğitimi hizmet içi eğitim programına ilişkin görüşleri. Kalem Eğitim ve Insan Bilimleri Dergisi, 1(1), 189 - 226.

Sabel, C., Saxenian, A., Miettinen, R., Kristensen, P.H., \& Hautamäki, J. (2011). Individualized service provision in the New Welfare State: Lessons from special education in Finland. Retrieved From http://people.ischool.berkeley.edu/ anno/Papers/individualized_ service_provision.pdf

Sarı, H., Çeliköz, N. ve Seçer, Z. (2009). An analysis of pre-school teachers' and student teachers' attitudes to inclusion and their selfefficacy. International Journal of Special Education, 24, 30-44.

Sart, H., Ala, H., Yazlık, Ö. ve Kantaş Yılmaz, F. (2004). Türkiye kaynaştırma eğitiminde nerede: Eğitimciye öneriler. XIII. Ulusal Eğitim Bilimleri Kurultayı, 6-9 Temmuz 2004 İnönü Üniversitesi, Eğitim Fakültesi, Malatya.

Sucuoğlu, B., Bakkaloğlu, H., İşcen Karasu, F., Demir, Ş., \& Akalın, S. (2013). Inclusive preschool teachers: Their attitudes and knowledge about inclusion. International Journal of Early Childhood Special Education (INT-JECSE), 5(2), 107-128.

Swedish National Agency for Education [SNAE]. (2011). Curriculum for the Preschool Lpfö 1998.Revised 2010. Retrieved April 25, 2017 from http://www.ibe.unesco.org/curricula/sweden/sw_ppfw_2010_eng.pdf

Takala, M., \&Aunio, P (2007). Exploring a new inclusive model in Finnish early childhood special education: a 3-year follow up study. International Journal of Inclusive Education, 9(1), 39-54.

Temel, F. (2000). Okul öncesi eğitimcilerinin engellilerin kaynaştırılmasına ilişkin görüşleri. Hacettepe Üniversitesi Eğitim Fakültesi Dergisi, $18,148-155$.

Tufan, M. ve Yıldırım, Y. (2013). Okul öncesi öğretmenlerinin erken müdahale ve kaynaştırma kavramları hakkındaki bilgi düzeylerinin ve özel gereksinimli çocuklar için yaptıkları öğretimsel uyarlamaların incelenmesi. Cumhuriyet International Journal of Education, 2(4), 1-13.

Tuş, Ö. ve Çiftçi Tekinarslan, ì. (2013). Okul öncesi kaynaştırma eğitimine devam eden özel gereksinimli çocukların karşılaştikları güçlüklerin annelerin görüşlerine göre belirlenmesi. Dumlupınar Üniversitesi Sosyal Bilimler Dergisi, 35, 151-166.

United Nations Educational, Scientific and Cultural organization[UNESCO], (1994). The Salamanca Statement and Framework for Action on Special Needs Education. Paris.

United Nations Educational, Scientific and Cultural organization [UNESCO], (2012). World data on education, Norway. [Brochure].

Zakirova Engstrand, R., \& Roll-Pettersson, L. (2014). Inclusion of preschool children with autism in Sweden: attitudes and perceived efficacy of preschool teachers. Journal of Research in Special Educational Needs, 14(3), 170.

| Kastamonu Eğitim Dergisi, 27(4), 2019| 